\title{
Clinical presentation of influenza a (H1N1) infection in a local emergency department in Greece
}

Evangelos Voudoukis ${ }^{*}$, Athanasios Panoutsopoulos, Pappas Apostolos, Stofa Efthimia, Leventogianni Vassiliki, Mpoumpoukas Theodoros, Mylona Panagiota, Rozi Fotini, Andrianopoulos loannis, Andrianopoulos Georgios

From $16^{\text {th }}$ International Symposium on HIV and Emerging Infectious Diseases

Marseille, France. 24-26 March 2010

\section{Background}

After the global spread of the new swine-origin influenza virus A (H1N1) the World Health Organization raised the level of influenza pandemic alert up to phase 6 , thus declaring a public health emergency of major importance. In response to this declaration many countries, including ours, organized a network for the reporting, diagnosis, and treatment of influenza A (H1N1) infection. Our aim is to report the epidemiological and clinical characteristics of H1N1 infected patients, who presented to our local emergency department and compare their clinical features with patients with common influenza-like symptoms who tested negative for the H1N1 virus.

\section{Methods}

Our study included forty-five patients with influenza-like symptoms who presented to the emergency department of General Hospital of Argos from July to August 2009 and whose medical history was suggestive Clinical examination, blood and $x$-ray tests were conducted in all patients. In addition, pharyngeal swabs were obtained and tested for detection of H1N1 virus by real-time reverse transcription-PCR (RT-PCR) of H1N1 infection.

\section{Results}

We examined 26(57.8\%) males and 19(42.2\%) females, with an average age of 30 years old. Eighteen cases (40\%) were positive for the H1N1 virus. The patients clinical and laboratory data are presented in Table 1. Forty-one percent of the infected patients came in contact with a verified case of $\mathrm{H} 1 \mathrm{~N} 1$ infection, $18 \%$ had recently traveled abroad and $41 \%$ had no whatsoever obvious cause of infection. This study included 3 families of whom 8 members out of 9 were found positive. Statistical analysis showed that the number of white blood cells were significantly higher in patients who tested negative for the H1N1 infection $(8.910 \pm$ 4.250 vs $6.670 \pm 2.340, \mathrm{P}<0.05)$ compared to the H1N1 infected patients. No significant differences were found between H1N1 positive and negative patients with respect to the patients' age and gender, duration of illness, presence of fever and serious complications.

\section{Discussion}

The clinical characteristics of the new influenza A (H1N1) appeared mild and resembled those of common influenza-like illness. The patients who tested negative for the H1N1 virus had a higher mean value of white blood cells; nonetheless their number remained within the normal reference range of our laboratory. Further studies are necessary in order to verify these results.

Published: 11 May 2010

* Correspondence: v.voudoukis@hotmail.com

Department of internal medicine of General Hospital of Argos, Argos, Greece

doi:10.1186/1742-4690-7-S1-P184

Cite this article as: Voudoukis et al: Clinical presentation of influenza a (H1N1) infection in a local emergency department in Greece.

Retrovirology 2010 7(Suppl 1):P184. 
Table 1 Patients' clinical and laboratory data

\begin{tabular}{|c|c|c|c|}
\hline & $\begin{array}{l}\mathrm{H} 1 \mathrm{~N} 1(+) \\
\mathrm{N}=18\end{array}$ & $\begin{array}{l}\text { H1N1(-) } \\
\mathrm{N}=27\end{array}$ & P VALUE \\
\hline Age (mean \pm SD) & $28.3 \pm 12.8$ & $31.2 \pm 13.5$ & 0.468 \\
\hline White Blood Cells (mean \pm SD) & $6.670 \pm 2.340$ & $8.910 \pm 4.250$ & 0.049 \\
\hline Duration of Illness (days) (mean \pm SD) & $5.22 \pm 1.99$ & $5.22 \pm 1.99$ & 1.000 \\
\hline Gender (male/female) & $9 / 9(50 \% / 50 \%)$ & $17 / 10(63 \% / 37 \%)$ & 0.388 \\
\hline White Blood Cells & & & 0.095 \\
\hline Normal & $15(83.3 \%)$ & $22(81.5 \%)$ & \\
\hline High & $0(0 \%)$ & $4(14.8 \%)$ & \\
\hline Low & $3(16.7 \%)$ & $1(3.7 \%)$ & \\
\hline Neutrophilles & & & 0.172 \\
\hline Normal & $13(72.2 \%)$ & $17(63 \%)$ & \\
\hline High & $1(5.6 \%)$ & $7(25.9 \%)$ & \\
\hline Low & $4(22.2 \%)$ & $3(11.1 \%)$ & \\
\hline Lymphocytes & & & 0.816 \\
\hline Normal & $8(44.4 \%)$ & $13(48.1 \%)$ & \\
\hline High & $4(22.2 \%)$ & $4(14.8 \%)$ & \\
\hline low & $6(33.3 \%)$ & $10(37.1 \%)$ & \\
\hline Monocytes & & & 0.393 \\
\hline Normal & 7 (38.9\%) & $14(51.9 \%)$ & \\
\hline High & $11(61.1 \%)$ & $13(48.1 \%)$ & \\
\hline Fever & & & 0.420 \\
\hline$\geq 38$ & $14(77.8 \%)$ & $18(66.7 \%)$ & \\
\hline$<38$ & $4(22.2 \%)$ & $9(33.3 \%)$ & \\
\hline Hospital admission (no/yes) & $15 / 3(83.3 \% / 16.7 \%)$ & 26/1 (96.3\%/3.7\%) & 0.134 \\
\hline Complications (no/yes) & $17 / 1$ & $25 / 2$ & 0.807 \\
\hline Bronchitis & $1(5.6 \%)$ & - & \\
\hline Pneumonia & - & $2(7.4 \%)$ & \\
\hline
\end{tabular}

